\title{
Chapter 13 \\ Immunities of International Organizations \\ Before Domestic Courts: Reflections \\ on the Collective Labour Case Against \\ the European Patent Organization
}

\section{Cedric Ryngaert}

Abstract The Netherlands is home to a substantial number of international organizations, which on the basis of international agreements are entitled to immunity from jurisdiction and enforcement before Dutch courts. This immunity grant has not stopped claimants from suing international organizations in The Netherlands, sometimes successfully. Dutch courts have indeed proved willing to entertain claims that a particular activity of the organization was not necessary for the fulfilment of its functions, or that the organization failed to offer an alternative remedy. In a recent case against the European Patent Organization, a Dutch court dismissed the organization's immunity on the ground that it failed to offer an alternative remedy and that the impugned substantive violations rose to the level of fundamental rights violations. The author supports this approach, with some reservations, but regrets the quasi-absolute immunity from enforcement which international organizations continue to enjoy.

Keywords Immunity - International organizations - The Netherlands - Right to a remedy - Collective labour law

Professor of Public International Law, Utrecht University. The research which resulted in this publication has been funded by the European Research Council under the Starting Grant Scheme (Proposal 336230 - UNIJURIS) and the Dutch Organization for Scientific Research under the VIDI Scheme.

C. Ryngaert ( $\square)$

Utrecht University, Utrecht, The Netherlands

e-mail: c.m.j.ryngaert@uu.nl 


\section{Contents}

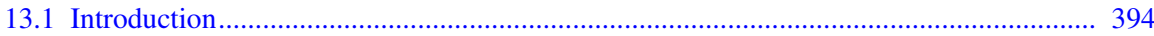

13.2 The Collective Labour Dispute Involving the European Patent Organization

Before Dutch Courts ................................................................................................... 397

13.3 Immunity from Jurisdiction: Some Reflections ………................................................ 398

13.3.1 The 'Additional Circumstances' Test ................................................................ 399

13.3.2 The Standard of Manifest Deficiency ................................................................... 402

13.3.3 The Normative Relationship Between Immunity Agreements

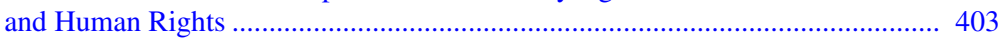

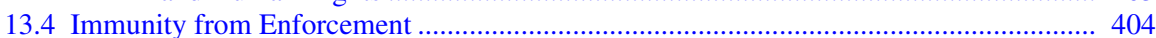

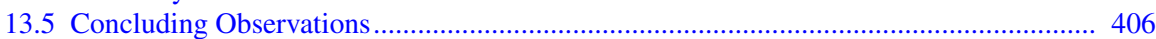

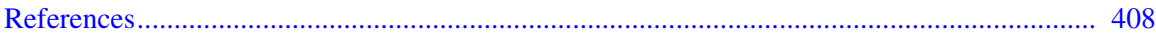

\subsection{Introduction}

The Netherlands is home to a substantial number of international organizations, which on the basis of international agreements are entitled to immunity from jurisdiction and enforcement before Dutch courts. ${ }^{1}$ This immunity grant has not stopped claimants from suing international organizations in The Netherlands, sometimes successfully. In essence, claimants have made two sorts of arguments: (1) that a given activity of the organization was not necessary to discharge the functions assigned to it; (2) that the organization did not offer alternative means of dispute settlement. The first argument has had some traction in Dutch courts, with the Court of Appeal of Amsterdam, in a criminal case against Euratom, dismissing the organization's immunity on the grounds that violating Dutch environmental regulations did not form part of the organization's functions, ${ }^{2}$ and the Court of Appeal of The Hague, in a procurement case against the European Patent Organization (EPO), dismissing the organization's immunity on the grounds that offering catering facilities was unrelated to the EPO's function of issuing patents. ${ }^{3}$ The second argument, based on the principle which the European Court of Human

\footnotetext{
${ }^{1}$ Exceptionally, Dutch courts have been willing to ground an organization's immunity directly on customary international law, in the absence of headquarters or other international agreement. See A. Spaans v. The Netherlands, Supreme Court, NJ 1986/438, 20 December 1985.

2 The Court of Appeal was, however, overruled by the Supreme Court, which did grant the organization functional immunity. See Euratom, Supreme Court (criminal case), LJN: BA9173, 13 November 2007 (and the summary of the Court of Appeal's judgment cited therein).

${ }^{3}$ European Patent Organization v. Stichting Restaurant de la Tour, Court of Appeal The Hague, No. 200.065.887/01, LJN: BR0188, 21 June 2011.
} 
Rights laid down in Waite and Kennedy, ${ }^{4}$ has been entertained by Dutch courts, but so far not led to a dismissal of immunity-exception in the collective labour case against the EPO discussed below. In individual labour cases-the typical cases coming before domestic courts-Dutch courts have acknowledged the applicability of the principle, and have ruled that the International Labour Organization Administrative Tribunal was a reasonably available alternative means of disputesettlement, thus confirming the immunity of organizations, such as the EPO, using this tribunal for individual labour disputes. ${ }^{5}$ In the Mothers of Srebrenica case, however, the Supreme Court held that the principle was not applicable to litigation against the United Nations in respect of its peace and security mandate; this position was later confirmed by the European Court of Human Rights. ${ }^{6}$ In the recent scholarly literature, both in English and Dutch, fine descriptions of the pertinent cases, as well as critical comments thereto, can be found. ${ }^{7}$

In the limited space allotted to me here, I will not repeat these analyses. Rather, I would like to reflect on one particular case that recently made headlines in the Netherlands, namely, a case filed against the European Patent Organization (EPO) by two of its trade unions in respect of the organization's restrictions of collective labour rights, leading to two court decisions and a ministerial order (2014-2015).

The EPO is an international organization set up to strengthen co-operation between the states of Europe in respect of the protection of inventions. It has an establishment in Rijswijk, close to The Hague, whereas its main establishment is in Munich, Germany. The EPO had earlier been sued before Dutch courts, namely concerning a public procurement case concerning catering activities and an individual labour dispute. As set out above, in the former case, The Hague Court of Appeal (2011) rejected the EPO's immunity defence on the ground that offering a catering facility was not strictly necessary to the end of granting patents. ${ }^{8}$ In the latter case, the Dutch Supreme Court (2009) held that the EPO could avail itself of its immunity as it had made available an alternative dispute settlement mechanism

\footnotetext{
${ }^{4}$ Waite and Kennedy $v$ Germany, ECtHR, No. 26083/94, 18 February 1999, para 68. 'It should be recalled that the Convention is intended to guarantee not theoretical or illusory rights, but rights that are practical and effective. This is particularly true for the right of access to the courts in view of the prominent place held in a democratic society by the right to a fair trial ... For the Court, a material factor in determining whether granting [the European Space Agency, an international organization headquartered in Germany] immunity from German jurisdiction is permissible under the Convention is whether the applicants had available to them reasonable alternative means to protect effectively their rights under the Convention.'

${ }^{5}$ Court of Appeal The Hague, No. 01/136, NIPR 2004, No. 268, 13 February 2002; Claimant v. European Patent Office, Supreme Court, No. 08/00118, LJN: BI9632, 23 October 2009.

${ }^{6}$ Stichting Mothers of Srebrenica and others v. United Nations, Case No. 10/04437, 13 April 2012, Supreme Court, ILDC 1760 (NL 2012), para 4.3.3; Stichting Mothers of Srebrenica and others v. The Netherlands, ECtHR, No. 65542/12, 27 June 2013, para 165. The Court of Appeal, however, did apply Waite and Kennedy. Stichting Mothers of Srebrenica and others v. United Nations, Court of Appeal The Hague, Case No. 200.022.151/01, 30 March 2010.

7 Schrijver 2013; Henquet 2010, 2013; and Dekker and Ryngaert 2011.

${ }^{8}$ European Patent Office v. Stichting Restaurant de la Tour, para 14.
} 
effectively guaranteeing a staff member's right to a remedy. ${ }^{9}$ The case that is the subject of this note constitutes the first collective labour dispute involving the $\mathrm{EPO}$, or any other international organization for that matter, that was ever brought before Dutch courts.

Problems had arisen between the EPO and two of its trade unions (VEOB and SUEPO), which accused the organization of unduly limiting collective labour rights. After the EPO failed to heed the unions' demands in 2013, they filed suit against EPO before Dutch courts. In 2014, the District of The Hague court dismissed the case, citing the risk of fragmentation of the EPO. ${ }^{10}$ In 2015 , however, the Court of Appeal of The Hague held that the organization could not avail itself of its immunity from jurisdiction and went on to assess the merits of a claim brought by the unions. ${ }^{11}$ While the organization's immunity was laid down in the relevant headquarters agreement between the EPO and The Netherlands, ${ }^{12}$ this immunity could not, according to the Court, be relied on since the organization had not made alternative mechanisms of dispute settlement available to the claimants. This 'alternative means' test is derived from the Waite and Kennedy judgment (1999) of the European Court of Human Rights (ECtHR). ${ }^{13}$ The Court of Appeal then went on to consider the restrictions, which EPO had imposed on trade union formation and communication, as well as the right to strike, as violations of fundamental collective labour rights. The remedy, which the Court imposed, consisted of giving the trade unions unimpeded access to the EPO's internal mailing system, of allowing them to participate in collective labour negotiations, and of prohibiting the organization from applying the provisions of its service regulation, which limited the right to strike. Eventually, however, the Minister of Justice and Security ordered the bailiff not to enforce the Court's decision on the ground that enforcement would amount to a violation of the EPO's internationally protected immunity from execution. ${ }^{14}$

The EPO case is internationally relevant in two respects: (1) because the Court of Appeal rejected the international organization's claim of immunity from jurisdiction on human rights grounds, transposing to collective labour disputes the Waite and Kennedy test developed by the European Court of Human Rights in the

\footnotetext{
${ }^{9}$ Supreme Court of the Netherlands, ECLI:NL:PHR:2009:BI9632, 23 October 2009, para 3.5.

${ }^{10}$ District Court The Hague, ECLI:NL:RBDHA:2014:420, 14 January 2014.

${ }^{11}$ Court of Appeal The Hague, ECLI:NL:GHDHA:2015:255, 17 February 2015. I have discussed this case with my co-author Frans Pennings in Ryngaert and Pennings 2015a and 2015b.

12 Article 3(1) of the 1973 Protocol on Privileges and Immunities of the European Patent Organization, 1050 UNTS 500 (EPO Protocol); Article 8 of the 1973 Convention on the Grant of European Patents, 1065 UNTS 199 (EPO Convention).

13 Waite and Kennedy v Germany, para 68.

${ }^{14}$ Ministerie van Veiligheid en Justitie, Directoraat-Generaal Rechtspleging en Rechtshandhaving, Directie Juridische en Operationele Aangelegenheden, Aanzegging ex artikel 3a, tweede lid, van de Gerechtsdeurwaarderswet, 23 February 2015.
} 
context of individual labour disputes; ${ }^{15}$ and (2) because it affirmed the international organization's quasi-absolute immunity from execution. The case invites some broader reflections from my side regarding the relationship between an international organization's treaty-based immunity from jurisdiction and fundamental human rights, as well as regarding the scope of the organization's immunity from execution. I will proceed in three stages. First, I give a short overview of the decisions of the District Court and the Court of Appeal. Secondly, starting from these decisions, I voice some critical comments regarding international organizations' immunity from jurisdiction measured against claimants' rights of access to a remedy. Thirdly, taking the Minister's decision to block enforcement of the judgment against the EPO as my starting point, I criticize the quasi-absolute immunity from execution of which international organizations can still avail themselves.

\subsection{The Collective Labour Dispute Involving the European Patent Organization Before Dutch Courts}

As noted in the introduction, EPO had earlier been sued before a Dutch court in an individual labour dispute. In that case the Dutch Supreme Court, applying the Waite and Kennedy principle, had held that EPO could avail itself of its immunity on the ground that it had made available an alternative dispute settlement mechanism effectively guaranteeing the individual claimant's right to a remedy under Article 6 of the European Convention on Human Rights (ECHR): ${ }^{16}$ individual staff members of EPO indeed had access to a jurisdictional procedure before the Administrative Tribunal of the International Labor Organization (ILOAT), even if they were not entitled to a public hearing. ${ }^{17}$ The ILOAT does not have jurisdiction, however, over collective labour disputes between international organizations and trade unions, nor do international organizations normally provide for other collective labour-related alternative disputesettlement mechanisms that could satisfy the Waite and Kennedy standard. Collective labour disputes have not earlier been brought before Dutch courts nor-to my knowledge - before other domestic courts. Thus, VEBO/SUEPO v EPO constitutes a primer that may serve as a precedent.

In 2013, the trade unions in question had requested the (first instance) District Court of The Hague to force EPO to terminate violations of the right to strike and the right to collective negotiations. The District Court rendered a somewhat confused decision on 14 January 2014, first rejecting and subsequently upholding EPO's

\footnotetext{
15 Waite and Kennedy, para 68.

161950 Convention for the Protection of Human Rights and Fundamental Freedoms, 213 UNTS 222 (ECHR).

${ }^{17}$ Supreme Court of the Netherlands, ECLI:NL:PHR:2009:BI9632, 23 October 2009, para 3.5. The Court held that the claimants had not established that the ILOAT would decline motivated requests to hold a public hearing (although in practice such hearings were rarely held).
} 
immunity. On the one hand, it ruled that EPO was not entitled to immunity as the trade unions did not have access to an effective remedy under Article 6 ECHR. ${ }^{18}$ On the other hand, it decided that upholding the claims could result in fragmentation of EPO, in the sense that in The Netherlands different rules than in other participating EPO States (in particular Germany) would be applied. This would allegedly impinge on the essence of the immunity, in violation of the EPO Convention, which safeguards the functioning of EPO as a whole, including the application of organizationwide and uniform regulation. ${ }^{19}$ According to the Court, the trade unions would instead have to submit their claims to the central organization of EPO in Germany. ${ }^{20}$ The Court's reasoning is open to criticism as it oddly relies on organizational necessity to limit the trade unions' right to a remedy, whereas normally, the right to a remedy is resorted to so as to limit adverse effects of an organizational necessity analysis.

On appeal, the Court of Appeal of The Hague struck down the first instance judgment, notably on the ground that the unions had not intended to fragment the organizational rules, even if these had been set for the entire organization. In so doing, it appeared to reject the argument that EPO's immunity was necessary for the exercise of the organization's competences, at least insofar as no similar cases were pending before other states' courts. Relying on human rights considerations, the Court went on to characterize the impugned violations - of the right to strike and the right to collective negotiations - as violations of fundamental rights. ${ }^{21}$ In addition, it held, applying the Waite and Kennedy principle, that the judicial protection offered by EPO in respect of alleged violations of the right to collective action and negotiation was 'manifestly deficient' since the procedure before ILOAT is limited to individual staff members ${ }^{22}$ and because EPO had not provided any remedy to safeguard collective labour rights. ${ }^{23}$ The Court then went on to hold EPO's invocation of immunity with respect to the trade unions' prima facie claims, in the absence of any alternative judicial protection, to be a disproportionate restriction of the right of access to a court, laid down in Article 6 ECHR. ${ }^{24}$

\subsection{Immunity from Jurisdiction: Some Reflections}

Even while I agree with the outcome of the case (the rejection of EPO's immunity from jurisdiction on human rights grounds), in this section I provide a critique of three considerations of the Court: (a) that the unavailability of an alternative

\footnotetext{
${ }^{18}$ District Court The Hague, ECLI:NL:RBDHA:2014:420, 14 January 2014.

${ }^{19}$ Ibid., para 3.11.

${ }^{20}$ Ibid.

${ }^{21}$ Court of Appeal The Hague, ECLI:NL:GHDHA:2015:255, 17 February 2015, paras 3.7 and 3.10 .

22 Ibid., para 3.8.

${ }^{23}$ Ibid., para 3.9.

24 Ibid., para 3.10.
} 
means of dispute settlement does not ipso facto lead to the rejection of an international organization's immunity; (b) that an international organization's immunity is only lifted in case the available mechanisms of dispute settlement are manifestly deficient; and (c) that human rights prevail over immunity agreements.

\subsubsection{The 'Additional Circumstances' Test}

It bears notice that the Court found violations of substantive and procedural human rights, namely of fundamental social rights and of the right to a remedy (access to a dispute settlement mechanism) under Article 6 ECHR, and it found that only the combination of both violations led to the (automatic) rejection of the organization's immunity. Directly relying on the Waite and Kennedy judgment, where the ECtHR held that the availability of an alternative remedy is just a 'material factor' in determining whether granting immunity is permissible, ${ }^{25}$ the Court of Appeal averred that the absence of an alternative remedy, combined with a conferral of immunity, does not ipso facto amount to a violation of Article 6 ECHR. According to the Court, such a violation can only be found in case of 'additional circumstances', in particular the systematic and far-reaching violation of the fundamental principles of the rule of law, ${ }^{26}$ in the case collective labour rights. This reasoning implies, a contrario, that in case the underlying violation does not rise to the level of an (international) human rights violation-say a breach of (employment) contract-a domestic court is allowed to uphold the immunity of the organization, even if it does not offer an alternative remedy to the claimant. In my view, this is an overly restrictive interpretation of the protection offered by Article 6 ECHR, which, moreover, does not find support in recent case-law of the ECtHR. From the ECtHR's decision (preceding The Hague Court of Appeal's decision in EPO) in Klausecker $v$ Germany (2015), a case concerning-as it happened-the immunity of EPO, it follows that, at least in individual labour disputes, the availability of an alternative means of dispute settlement is a necessary condition for the organization to avail itself of its immunity, ${ }^{27}$ without further requirements being imposed regarding the character of the underlying violation allegedly committed by the organization.

Outside the context of individual labour disputes, an affirmation of the immunity of international organizations, even in the absence of alternative means of dispute settlement being made available to the claimants, may arguably be permissible in limited circumstances. The most obvious scenario is where the

\footnotetext{
25 Waite and Kennedy, para 68.

${ }^{26}$ Court of Appeal The Hague, ECLI:NL:GHDHA:2015:255, 17 February 2015, para 3.10.

${ }^{27}$ Klausecker v. Germany, ECtHR, No. 415/07, 6 January 2015, para 69. 'Having regard to the importance in a democratic society of the right to a fair trial, of which the right of access to court is an essential aspect, the Court therefore considers it decisive whether the applicant had available to him reasonable alternative means to protect effectively his rights under the Convention.'
} 
nature and the mission of the organization are such that lifting its immunity would produce serious adverse effects on world peace. This exception, drawn from consequentialist ethics, may justify the affirmation of the immunity of the United Nations in respect of acts committed in the framework of peace operations, even where the impugned acts amount to gross human rights violations. As Steven Ratner, in his remarkable The Thin Justice of International Law (2015), recently argued, a norm of international law, e.g. on immunity, even if does not fully respect fundamental human rights, may be morally justified if at least it furthers international peace. ${ }^{28}$ For this reason, he considered the personal immunity of heads of State and heads of government in office defensible, because rejection of such immunity may cause international tension, possibly leading to inter-state war. ${ }^{29}$ Along similar lines, a failure to confer immunity may make the United Nations reluctant to authorize such operations, and the member states to contribute troops, with dire consequences for international peace and security: vicious civil wars, with the attendant human toll, may continue unabated. The Dutch Supreme Court and the ECtHR appear to have relied on this argument in their Mothers of Srebrenica judgments, in which they held that the conferral of immunity of the UN by Dutch courts in respect of UN peacekeeping failures was not a violation of Article 6 ECHR, even if the UN had not provided alternative dispute settlement mechanisms (in fact, unlike what, in 1946, was envisaged in Section 29 of the UN Convention on the Privileges and Immunities of the UN). ${ }^{30}$ According to the Dutch Supreme Court, in the context of maintaining international peace and security, the immunity of the UN was absolute, and states would be under an obligation, pursuant to Article 103 of the UN Charter, to give priority to their UN obligations over obligations flowing from any other international agreements, such as human rights obligations under the ECHR. ${ }^{31}$ The ECtHR has supported this approach in its 2013 judgment, in which it held that it does not follow from Waite

\footnotetext{
${ }^{28}$ Ratner 2015, at 64.

${ }^{29}$ Ibid., at 204. Note that Ratner considered other forms of immunity to be unjust on the ground that they overly restrict the enjoyment of human rights without evidence being offered of such immunities furthering international peace. Ibid., at 411.

${ }^{30}$ Section 29 of the 1946 UN Convention on the Privileges and Immunities of the UN, 1 UNTS 15. This section provides that the UN shall make provisions for appropriate modes of settlement of disputes arising out of contracts or other disputes of a private law character to which the UN is a party, but such modes have never been established. In practice, the UN settles disputes arising out of peacekeeping operations administratively, via ex gratia payments or lump sum agreements with host States, without offering judicial guarantees. See Schmalenbach 2006.

31 Stichting 'Mothers of Srebrenica' c.s. tegen de Staat der Nederlanden en de VN, Hoge Raad 13 April 2012, LJN: BW19, paras 4.3.5-4.3.6. For an extensive discussion of the decisions of the Supreme Court, the Court of Appeal, and the District Court in this case, see Schrijver 2013.
} 
and Kennedy that 'the absence of an alternative remedy the recognition of immunity is ipso facto constitutive of a violation of the right of access to a court'. ${ }^{32}$ The ECtHR considered that such a rule may perhaps be applicable to employment disputes, but that the Mothers of Srebrenica case was 'fundamentally different from [these] earlier cases' ${ }^{33}$ given the special nature of the United Nations as a collective security organization. ${ }^{34}$

The Court of Appeal in the EPO case has, somewhat unfortunately, seised on the ECtHR's pronouncement in Mothers of Srebrenica to condition the dismissal of immunity on 'additional circumstances' being present, beyond just the unavailability of alternative means of dispute settlement, ${ }^{35}$ whereas the ECtHR did no more than drawing attention to the special position of the UN as a collective security organization. As far as the collective labour dispute at issue was concerned, the importance of these 'additional circumstances' should not be exaggerated, however, as a considerable number of basic collective employment rights rise to the level of fundamental rights. ${ }^{36}$ Still, under the standard suggested by the Court of Appeal, an international organization may continue to avail itself of immunity with regard to disputes over detailed regulations in collective labour agreements between an international organization and its trade unions, even if it has not provided for an alternative dispute settlement mechanism. It remains elusive in this respect what additional circumstances-apart from fundamental rights violations - could nevertheless set aside this immunity in these cases. In my view, the 'additional circumstances' test has no place in collective or individual labour disputes, and should be limited to the very specific case of the UN in its capacity as a collective security organization; in other cases, the international organization's immunity should be conditioned on its making available alternative means of dispute settlement.

\footnotetext{
32 Stichting Mothers of Srebrenica and others $v$ the Netherlands, ECtHR, No. 65542/12, 27 June 2013, para 164. The Court drew attention to Waite and Kennedy's enunciation that the absence of an alternative dispute settlement mechanism was only "material factor" in determining whether granting an international organisation immunity from domestic jurisdiction was permissible.' Ibid., para 163.

33 Ibid., paras 149 and 165.

34 The Court finds that since operations established by United Nations Security Council Resolutions under Chapter VII of the United Nations Charter are fundamental to the mission of the United Nations to secure international peace and security, the Convention cannot be interpreted in a manner which would subject the acts and omissions of the Security Council to domestic jurisdiction without the accord of the United Nations. Ibid., para 154 (citing its decision in Behrami, in which it refused to hold UN member States responsible for violations committed in the context of UN peace operations). Behrami and Behrami $v$ France and Saramativ France, Germany and Norway, ECtHR, Nos. 71412/01 and 78166/01, 2 May 2007.

35 Court of Appeal The Hague, ECLI:NL:GHDHA:2015:255, 17 February 2015, para 3.4.

${ }^{36}$ See for a list of fundamental collective labour rights Articles 1-10 of the 1961 European Social Charter, 529 UNTS 89.
} 


\subsubsection{The Standard of Manifest Deficiency}

Where international organizations duly make alternative dispute settlement mechanisms available to claimants, the next question is what standards these mechanisms should meet. The Court of Appeal in the EPO case seemed to imply that the remedies offered by the organization need not be perfect; as long as they are not 'manifestly deficient' they may satisfy the requirements of Article 6 ECHR. ${ }^{37}$ This standard of manifest deficiency does, however, not feature in the ECtHR's caselaw on the immunity of international organizations. Rather, it is borrowed from the ECtHR's Bosphorus-based case-law on the responsibility of member states for the internationally wrongful acts of international organizations, ${ }^{38}$ where it is used to hold a member state responsible for an ECHR violation in connection with an act of an international organization, even in a situation of the organization offering protection equivalent to the level of protection offered by the ECHR. ${ }^{39}$ By transposing the standard of manifest deficiency to the immunity of international organizations, the Court of Appeal appears to imply that Article 6 ECHR is only violated in cases of manifestly deficient protection. In so doing, it overlooks the requirement that, according to the Bosphorus principle, the organization is supposed to offer equivalent protection in the first place.

Arguably, by abandoning this prior requirement of equivalence, the Court may - possibly unconsciously — have lowered the threshold for a finding of immunity. Indeed, a rudimentary mechanism offered by the organization to settle disputes may well not be manifestly deficient, while nevertheless offering only limited judicial protection. A la limite, even the mere existence of a dispute settlement mechanism may pass muster when the manifest deficiency standard is used. Truth be told, however, while, as indicated above, the standard of manifest deficiency is not used by the ECtHR in its case-law on the immunity of international organizations, friendly treatment of the organization may not only follow from the application of the manifest deficiency standard but also of the 'reasonably available alternative means' standard. There is, indeed, quite some case-law of courts, including case-law of the ECtHR itself, paying deference to international organizations even where the dispute settlement mechanisms, which they made available, were hardly up to standard. ${ }^{40}$ In my view, while domestic courts need not require protection identical to the protection offered by the ECHR (as such a requirement may pay insufficient justice to the autonomy of international

37 Court of Appeal The Hague, ECLI:NL:GHDHA:2015:255, 17 February 2015, paras 3.8-3.9. Note that the Court held that in the case, the remedies were indeed manifestly deficient.

38 Bosphorus v. Ireland, ECtHR, No. 45036/98, 30 June 2005. The case is cited in Court of Appeal The Hague, ECLI:NL:GHDHA:2015:255, 17 February 2015, para 3.6.

39 Bosphorus v. Ireland, paras 155-156.

40 See notably Chapman v. Belgium, ECtHR, No. 39619/06, 5 March 2013 (regarding the compatibility with Article 6 ECHR of the procedures before the NATO Appeals Board, made available to NATO employees). For a discussion of relevant other cases, see Ryngaert 2010. 
organizations), they should not recoil from inquiring into the quality of the dispute settlement mechanisms offered by the organization and reject the organization's immunity defence where these mechanisms are not just manifestly deficient but also where they fail to offer equivalent protection.

\subsubsection{The Normative Relationship Between Immunity Agreements and Human Rights}

A final point to be made, as far as the Court of Appeal's holding on the EPO's immunity from jurisdiction is concerned, pertains to the legal relationship between the Protocol on the Privileges and Immunities of EPO, on the one hand, and the ECHR and/or fundamental (social) rights, on the other. The Court implied that the latter prevail over the former, ${ }^{41}$ but it remained silent on the normative justification of this prevailing effect. Such an effect is not self-evident, however, as there is no principled normative hierarchy between a headquarters agreement/protocol on privileges and immunities and a human rights treaty. The lex specialis and lex posterior canons of treaty construction are of no particular use in this respect as both categories of treaties cover very different subject-matters. The better argument is that human rights treaties do not prevail over immunity treaties, but that the latter treaties should be interpreted in light of international human rights norms on the ground that these are other 'relevant rules of international law applicable in the relations between the parties', in the sense of Article 31(3)(c) of the Vienna Convention on the Law of Treaties (1969), which enshrines one of the general rules of interpreting treaties. Accordingly, Article 6 ECHR, as interpreted by the ECtHR, informs the application of Article 3 of the Protocol on Privileges and Immunities of EPO, as result of which norms on human rights and immunities are balanced with each other. ${ }^{42}$ This balancing process ensures that an organization's immunity is not per se lifted when measured against norms of international human rights law on access to a court (otherwise no immunity would survive) but only where the organization fails to offer a minimum level of (quasi-)judicial protection to aggrieved individuals or entities.

\footnotetext{
${ }^{41}$ Court of Appeal The Hague, ECLI:NL:GHDHA:2015:255, 17 February 2015, para 3.11.

${ }^{42}$ See in this sense indeed Lutchmaya v. General Secretariat of the ACP, Court of Cassation (Belgium), Case No. C07 0407F, International Law in Domestic Courts, OUP, 1576 BE 2009, paras 30 and 32. The case avers that applying Article 6 ECHR in immunity cases involving international organizations comes down to balancing two norms, and that Belgium has not committed an internationally wrongful act by acceding to the instrument providing for immunity (the headquarters agreement).
} 


\subsection{Immunity from Enforcement}

The relevance of the EPO case does not only lie in the Court of Appeal's rejection of its immunity from jurisdiction on human rights grounds but also in the subsequent affirmation of its immunity from enforcement or execution. Precedents as far as enforcement measures against international organizations are concerned, are few and far between, for the simple reason that most claims against international organization strand at the jurisdictional stage. To my knowledge, only once has a high court endorsed the taking of enforcement measures against an organization; in 2009, the Belgian Court of Cassation lifted the immunity from enforcement of the Secretariat of the African, Caribbean, and Pacific Group of States (ACP) in an individual labour case, on the ground that the ACP had not made available alternative execution procedures to the claimant. ${ }^{43}$ The Belgian Court thus applied the Waite and Kennedy principle, developed with respect to an international organization's immunity from jurisdiction, to an organization's immunity from enforcement. How an organization could reasonably have provided an adequate alternative execution procedure in this case remained an open question, however.

The EPO case will not go down the annals as a second case of immunity from enforcement being rejected by a domestic court. While the case against the EPO did survive the jurisdictional stage, its enforcement was blocked by the Minister of Justice, who ordered the bailiff not to execute the Court of Appeal's judgment. The Minister has this power pursuant to a statutory provision, which provides that notification of execution measures should be refused insofar as such measures are incompatible with the Dutch state's obligations under international law. ${ }^{44}$ The provision is normally used to prevent enforcement measures from being taken against foreign states but, going by the text, its application can also extend to international organizations. In the past, for instance, the responsible Minister, supported by the Court of Appeal of The Hague, has blocked notification of a court judgment to the Organization for the Prohibition of Chemical Weapons (OPCW), concerning the payment of salary, on the ground that this notification and the ensuing threat of execution were incompatible with the internationally protected immunity from execution, as laid down in the headquarters agreement between The Netherlands and the OPCW. ${ }^{45}$ In this context, the Court of Appeal reaffirmed the well-known principle that immunity from execution is separate from immunity from jurisdiction $^{46}$ and that immunity from execution guarantees that the OPCW make use of its goods and properties unhindered by any execution measure. ${ }^{47}$ On the same

${ }^{43}$ Ibid.

${ }^{44}$ Articles 3a(2) and (5) Gerechtsdeurwaarderswet (Act on Bailiffs).

45 European Patent Organization v. Stichting Restaurant de la Tour. The Court referred to Article 4(2) of the headquarters agreement concluded between the Netherlands and the OPCW.

46 Ibid., para 4.

47 Ibid., para 6. 
ground, in another case against EPO, The Hague Court of Appeal held that the imposition of a non-compliance penalty (dwangsom) violated the principle of immunity from execution since such a penalty can be executed without any further judicial review. ${ }^{48}$

Immunity from execution may not only be invoked to block enforcement of monetary judgments but also to block enforcement of court injunctions. In the EPO case, for instance, the Court of Appeal did not order the organization to pay compensation to the claimants. Rather, it ordered the organization to carry out specific acts, such as giving the trade unions access to the EPO's internal mailing system. Obviously, such orders could be backed up by a non-compliance penalty, in which case measures of attachment against properties representing the value of the penalty could be taken. Such orders could, however, also be directly enforced by state authorities, e.g. by IT specialists hired by the government who penetrate the organization's computer systems so as to ensure compliance with the court order. Such direct enforcement will normally be accompanied by violations of the inviolability of the premises of the organization, unless representatives of the international organization happen to give their consent to enforcement.

Domestic authorities may believe that they have no other choice than to uphold an international organization's immunity from enforcement, as pursuant to headquarters agreements between international organizations and their host states, the former usually enjoy quasi-absolute immunity from enforcement in the framework of their official activities. The Protocol on the Privileges and Immunities of the EPO, for instance, provides unambiguously that properties and assets of the Organization are not subject to attachment, expropriation, confiscation, or any other enforcement measure, except insofar as the Organization has waived its immunity, the claim relates to an accident involve a motor vehicle, or the case concerns the execution of an arbitral award. ${ }^{49}$

Similar unambiguous wording also applies to international organizations' immunity from jurisdiction, but as discussed above, this has not stopped the ECtHR and domestic courts from dismissing an international organization's immunity from jurisdiction on human rights grounds. The question then arises whether human rights considerations could not equally inform the scope of an organization's immunity from execution and whether such considerations (should) differ from those that limit the organization's immunity from jurisdiction. For is the protection offered by the ECHR not illusory if claimants are precluded from executing a judicial decision against an international organization rendered in their favour?

The law of state immunity, in any event, while not abandoning the distinction between immunity from jurisdiction and immunity from execution, has allowed post-judgment measures of constraint to be taken against state property to the extent that it has been established that the property is specifically in use or intended for use by the state for other than government non-commercial purposes

\footnotetext{
48 European Patent Organization v. Stichting Restaurant de la Tour.

49 Article 3 of the EPO Protocol.
} 
and is in the territory of the state of the forum, ${ }^{50}$ even if, in practice, the implementation of such enforcement measures may be an uphill battle. ${ }^{51}$ No such exception has, however, found its way to headquarters agreements between states and international organizations or to customary international law on the immunity of international organizations (the latter being largely absent for that matter) ${ }^{52}$

From a policy perspective, and from the perspective of the claimants, it makes sense to also apply the commercial purpose exception to international organizations and not only to states. After all, the proper functioning of the international organization need not be impeded where measures of constraint are taken against property which it uses for commercial purposes and is thus not directly necessary for it to carry out its responsibilities. Where the claimant presents prima facie evidence that specific properties of the organization (e.g. bank accounts) are used for commercial purposes, post-judgment measures of constraint may well be taken against the organization. Alternatively, domestic courts may extend application of the Waite and Kennedy principle to immunity from enforcement, as the Belgian Court of Cassation did in 2009. This principle may in fact work to the advantage of the international organization, as it may allow organizations to take good faith execution measures that fall short of full execution, while still providing satisfaction to the claimants ('equivalent protection').

The ECtHR has never addressed the issue of immunity from execution before, but guidance from its side would be most welcome. It is not excluded that the lawyers of EPO trade unions will in due course submit an application to the ECtHR in case no compromise with the EPO can be found and the Dutch courts uphold EPO's immunity from execution.

\subsection{Concluding Observations}

The case against the European Patent Organization before Dutch courts has invited me to reflect on the scope of international organizations' immunities from jurisdiction and enforcement. I have supported The Hague Court of Appeal's rejection of EPO's immunity defence on human rights grounds. Nevertheless, I have appended some reservations to its reasoning, which admittedly led to the rejection of the organization's immunity but may prove unduly restrictive in future cases. Notably

\footnotetext{
${ }^{50}$ Article 19(c) of the 2004 UN Convention on Jurisdictional Immunities of States and their Property, Doc. A/59/508. The International Court of Justice has confirmed that this cardinal principle constitutes customary international law, although it doubted 'whether all aspects of Article 19 reflect current customary international law'. Jurisdictional Immunities of the State (Germany v. Italy: Greece Intervening), ICJ, Judgment of 3 February 2012, paras 117-118.

${ }^{51}$ For the difficulties of attaching embassy bank accounts, see Ryngaert 2013.

52 But see AS v. Iran-United States Claims Tribunal, Supreme Court, LJN AC9158, 20 December 1985 (conferring immunities on the Iran-U.S. Claims Tribunal, considered as an international organization, on the basis of customary international law).
} 
the principle that the unavailability of an alternative dispute settlement mechanism does not ipso facto lead to the rejection of immunity and the principle that internal organizational procedures need to be 'manifestly deficient' for immunity to be rejected are open to criticism. In addition, I have criticized the Minister's decision to prevent enforcement of the EPO judgment. Instead, I have suggested applying the rules of state immunity from execution to the immunity of international organizations; this would allow claimants to take enforcement measures against property of the organization that is used for commercial purposes. Alternatively, I have suggested applying the 'alternative means' Waite and Kennedy principle to immunity from execution.

Key is that claimants, aggrieved by acts of an international organization, should not be left in the cold. The principle of accountability demands that organizations should not lightly be allowed to invoke their immunity from jurisdiction and enforcement and that they be amenable to suit if no other remedy is available to the claimants. It is not certain that in future cases Dutch courts will be sensitive to this accountability argument. Seizing on para 68 of the ECtHR's Waite and Kennedy judgment, they may well reason that the (non-)availability of alternative mechanisms is just one material factor in the immunity determination, which could be outweighed by other factors, in particular the autonomy of the organization from Member State interference, and the specific tasks assigned to the organization. The ECtHR's Mothers of Srebrenica judgment, which rejected the applicability of Waite and Kennedy in peace and security-related cases brought against the UN, gives Dutch courts further ammunition for such a reasoning. To the extent that Dutch courts do accept Waite and Kennedy-mainly in individual labour cases and possibly in some other contractual cases-it is well possible that they will refrain from inquiring in-depth into the quality of the alternative mechanisms offered, and thus affirm the autonomy and immunity of the organization via the backdoor as it were. It is recalled in this respect that Dutch courts have upheld the immunity of the organization even if the dispute settlement mechanism offered by the latter failed to organize oral hearings - a basic tenet of a fair trial, one would assume. ${ }^{53}$ Alternatively, one may expect Dutch courts to further explore the avenue of rejecting the organization's immunity on the grounds that the impugned activity was not necessary to fulfil its functions. However, this avenue is largely a dead end, as in keeping with the principle of conferral organizations do not normally act ultra vires. Only where the organization engages in activities that are very incidental to its functions (e.g. catering, when issuing patents is the function of the organization), may the argument have some suasion.

It will now fall to the Supreme Court, hearing the appeal in the collective labour case against the EPO to clarify how functional necessity in the context of immunities will play out in future cases, and to what extent Waite and Kennedy applies beyond individual labour cases. In light of the Supreme Court's earlier case-law on the immunity of international organizations, I would not be surprised

53 Claimant v. European Patent Office, Supreme Court, No. 08/00118, LJN BI9632, 23 October 2009, para 3.5. 
if it were to confirm the Court of Appeal's rejection of the EPO's immunity. I refrain from extending this optimism to organizations' immunity from enforcement, however. Given the more invasive character of enforcing a judgment against an international organization, absent ECtHR guidance in this matter I do not expect Dutch courts to take the lead in restricting the immunity from enforcement.

\section{References}

Dekker I, Ryngaert C (2011) Immunity of international organizations: balancing the organization's functional autonomy and the fundamental rights of individuals. Mededelingen van de Nederlandse Vereniging voor Internationaal Recht 138. T.M.C Asser Press, The Hague, pp 83-109

Henquet T (2010) International organizations in the Netherlands: immunity from the jurisdiction of the Dutch courts. Neth Int Law Rev 57:267-284

Henquet T (2013) The jurisdictional immunity of international organizations in the Netherlands and the view from Strasbourg. Int Organ Law Rev 10:538-571

Ratner S (2015) The thin justice of international law. Oxford University Press, Oxford

Ryngaert C (2010) Immunity of international organizations before domestic courts: recent trends. Int Organ Law Rev 7:121-148

Ryngaert C (2013) Embassy bank accounts and state immunity from execution: doing justice to the financial interests of creditors. Leiden J Int Law 26:73-88

Ryngaert C, Pennings F (2015a) Fundamentele arbeidsrechten en immuniteit - de zaak tegen de Europese Octrooi Organisatie. Ned Juristenblad 90:1212-1218

Ryngaert C, Pennings F (2015b) Korte respons op de reactie van Niels Blokker. Ned Juristenblad 90:1837-1838

Schmalenbach K (2006) Third party liability of international organizations: a study on claim settlement in the course of military operations and international administrations. Int Peacekeeping 10:33-51

Schrijver N (2013) Srebrenica voorbij. De volkenrechtelijke immuniteit van de Verenigde Naties. In: Handelingen van de Nederlandse Juristenvereniging: Preadviezen immuniteiten. Het recht opzij gezet? 143:211-265 